\title{
KURVA SORPSI FOSFAT MENURUT LANGMUIR DAN FREUNDLICH SEBAGAI PENDUGA KEBUTUHAN PUPUK FOSFAT PADA ANDISOLS SUMATERA BARAT
}

\author{
Dian Fiantis \\ Laboratorium Genesis dan Klasifikasi Tanah \\ J urusan Tanah F akultas Pertanian U niversitas Andalas Padang
}

Abstract

Andisols are among the most productive soils in the world, but these soils also strongly retained phosphate. The high capacity for phosphate sorption in Andisols is due to their high content of active $\mathrm{Al}$ and Fe compounds. The objectives of this study were to assess the effect of soil properties on $P$ sorption, buffer capacities and requirements of some benchmark soil profiles in Mt. Marapi and Mt. Pasaman. The P sorption characteristics of Andisols from West Sumatra were described using Langmuir and Freundlich equations. The $P$ sorption maximum in Mt. Pasaman soils was higher than in Mt. Marapi soils. The most important soil properties affecting $P$ sorption and buffer capacities were oxalate $\mathrm{Si}$ and $\mathrm{Fe}, \mathrm{Al}\left(\mathrm{Si}_{\mathrm{o}} \mathrm{Fe}_{\mathrm{o}}\right.$ and $\left.\mathrm{Al} \mathrm{l}_{\mathrm{o}}\right)$, dithionite $\mathrm{Al}\left(\mathrm{Al}_{\mathrm{d}}\right)$, pyrophosphate $\mathrm{Al}\left(\mathrm{Al}_{\mathrm{p}}\right)$, which explained $89 \%$ of the variance in sorption maxima and $83 \%$ of $\mathrm{P}$ buffering indices. Allophane, $\mathbf{A l}_{\mathbf{o}}$ and $\mathrm{Al}_{\mathbf{d}}$ were positively correlated with $\mathrm{P}$ sorption maximum. Contrary to general assumption that organic matter had an inverse relation with $P$ sorption maxima, in this study, however, there was no trend observed between $P$ sorption maxima and organic carbon. Organic $\mathrm{C}$ has poor relationship with this parameter. Andisols from Mt. Marapi and Mt. Pasaman need $P$ input between 320 to 7,800 mg $P$ kg$^{-1}$ to maintain the $P$ level in soil solution at $0.2 \mathrm{mg} \mathrm{kg}^{-1}$.

Key words: Phosphate sorption curve, Andisols, Allofan

\section{PENDAHULUAN}

Propinsi Sumatera Barat terletak antara $0^{0} 54^{\prime}$ LU dan $3^{0} 30$ ' LS serta 98.36' BT dan $101^{0} \mathrm{BB}$ dengan luas lahan pertanian 1 juta hektar atau $24 \%$ dari luas wilayah. Ditinjau dari topografi atau bentuk wilayahnya, lebih dari $70 \%$ daerah di Sumatera Barat terletak di dataran tinggi atau pegunungan (Subardja, 1994). Ini diindikasikan dengan adanya 7 gunung api yaitu G. Marapi, G. Singgalang, G. Tandikat, G. Talang, G. Sago, G. Talamau dan G. Pasaman yang terletak pada jajaran pegunungan Bukit Barisan. Dengan demikian, tanah berbahan induk vulkanis tersebar cukup luas dan biasanya menjadi daerah sentra produksi pertanian. Kontribusi dari sektor pertanian untuk pertumbuhan ekonomi daerah ini mencapai $22 \%$ dan lebih dari $70 \%$ penduduk di wilayah ini bekerja di sektor pertanian (Kanisius, 1999). Jika memenuhi persyaratan sifat atau penciri tanah andik (andic soil properties), maka tanah vulkanis dapat diklasifikasikan ke dalam ordo Andisol (Soil Survey Staff, 1999) atau Andosol (FAOISRIC-ISSS, 1998).
Kreteria penciri tanah andik adalah tanah yang mempunyai kerapatan isi (Bulk Density) yang kecil atau sama dengan 0.90 $\mathrm{Mg} \mathrm{M}^{-3}, \mathrm{Al}_{0}+1 / 2 \mathrm{Fe}_{0}$ (Al dan $\mathrm{Fe}$ yang diekstrak dengan asam oksalat) besar atau sama dengan $2 \%$ dan retensi (sorpsi) $P$ haruslah lebih besar dari $85 \%$. Dengan demikian Andisol merupakan tanah yang mempunyai sifat tersendiri yang tak dijumpai pada tanah ordo lainnya.

Sifat dan ciri morphologi kimia, dan isika Andisol ini berkaitan erat dengan serilaku dan asal dari $\mathrm{Al}$ dan / atau Fe aktif yang terdiri dari mineral liat nonkristalin ;eperti alofan dan ferrihydrit serta mineral iat parakristalin 'imogolit' (Wada, 1989). Kehadiran senyawa aktif Al dan Fe yang sukup banyak dalam tanah menyebabkan $P$ erjerap kuat pada struktur mineral ini atau erikat pada gugus fungsional $\mathrm{OH}$ atau $\mathrm{H}$ vang bermuatan positif (Shoji et al., 1993).

Alofan merupakan mineral liat tanah vang paling reaktif karena mempunyai laerah permukaan khas yang sangat luas dan Janyaknya terdapat gugus fungsional yang 
aktif (Farmer et al., 1991).

Kehadiran alofan memberikan sifat-sifat yang khas pada tanah. Hal ini disebabkan alofan mempunyai muatan bervariasi yang besar, bersifat amfoter, KTK antara 20 sampai $50 \mathrm{cmol}(+) / \mathrm{kg}$ sedangkan KTA antara 5 sampai $30 \mathrm{cmol}(+) / \mathrm{kg}$, struktur yang acak dan terbuka serta dapat mengikat fosfat dalam jumlah yang banyak (Wada, 1989; Tan, 1992; Van Ranst, 1995). Akibat kuatnya fiksasi fosfat oleh mineral ini, maka ketersediaan fosfat yang mudah larut akan segera berkurang dan menurut Egawa (1977) hanya $10 \%$ dari pupuk $P$ yang diberikan dapat digunakan oleh tanaman. Tingginya persentase kehilangan pupuk $\mathbf{P}$ merupakan masalah serius yang banyak dijumpai pada tanah vulkanis.

Sorpsi $\mathbf{P}$ pada Andisol di Jepang dan Selandia Baru dilaporkan dapat mencapai 6000 mg kg-1 tanah dan kebutuhan $P$ untuk tanaman tentu saja akan melebihi angka ini. Hal yang serupa besar kemungkinan akan dijumpai pula pada Andisols di Sumatera Barat. Penelitian ini merupakan penelitian yang fundamental dan amat dibutuhkan sebelum melakukan penelitian terapan ataupun dalam penentuan strategi manajemen yang rasional untuk pengelolaan tanah vulkanis. Tersedianya informasi dan data yang tepat serta akurat akan sangat membantu peningkatan produktivitas dan konservasi tanah-tanah ini.

\section{METODA PENELITIAN}

\section{A. Bahan dan Alat}

Sebelum turun ke lapangan dilakukan studi kepustakaan tentang daerah yang akan diteliti. Informasi dari peta geologi. topografi serta peta tanah masing-masing dengan skala 1:250.000 akan digunakan untuk menentukan lokasi yang tepat dan dapat mewakili tanah yang akan diteliti.

Bahan yang digunakan dalam penelitian ini adalah tanah dari G. Marapi dan G. Pasaman yang mempunyai bahan induk tanah berasal dari batuan Andesit yang berumur kuarter untuk G. Marapi dan kuarter-tersier untuk tanah G. Pasaman. Contoh tanah diambil dari tanah pada toposequen sebelah Selatan G. Marapi yang terdiri dari 3 profil tanah dan 2 profil tanah pada toposequen sebelah utara $\mathbf{G}$. yang diwakili pula oleh 4 profil tanah. Jampel diambil dari tiap horizon tanah dan serjumlah 31 buah. Penetapan lokasi profil anah berdasarkan peta geologi, peta tanah lan peta topografi skala 1/40.000. Contoh anah telah dihaluskan dengan kehalusan $<2$ nm dan dalam keadaan kering udara.

Untuk survei dan pengambilan contoh ligunakan alat-alat standar ke lapangan ;eperti bor, cangkul, parang, meteran, GPS Geographical Positioning Satellite), Munsell soil Color Chart, kantong plastik, ring sampel dan lain-lainnya yang dianggap serlu. Alat yang digunakan di labor adalah jesuai dengan analisis yang akan dilakukan.

\section{Analisis Tanah}

Penentuan koloid Al dan Fe aktif lilakukan dengan analisis selective lissolution yaitu: (1) ekstraksi dengan DCB Jackson, 1965); (2) Ekstraksi dengan Ammonium Oksalat (Blakemore et al., 1987) Jan (3) Ekstraksi Asam Pirophosphat Blakemore et al., 1987).

Penentuan karakterisasi sorpsi $P$ lilakukan dengan analisis $\mathbf{P}$ Sorption [sotherm (Fox dan Kamprath, 1970) yaitu lengan cara penjenuhan tanah dengan rerbagai macam konsentrasi $P(0,25,50$, 100, 250 dan $500 \mathrm{mg} \mathrm{P} \mathrm{kg}$ ) selama 6 hari. Tanah dan larutan $P(1: 50)$ dikocok $2 \times 60$ nenit setiap hari dan pada hari keenam lisentrifus dan disaring. $P$ yang dijumpai jada supernatan dari larutan tanah kemudian lideteksi secara kolonimetri (P dalam larutan anah). Sedangkan $P$ yang yang tak erdeteksi merupakan $\mathbf{P}$ yang dijerap oleh anah. Dengan demikian sorpsi $P$ adalah ;elisih konsentrasi larutan $\mathbf{P}$ yang diberikan lengan $P$ yang terekstrak.

Data yang didapat dalam analsis diatas zemudian di masukkan ke dalam persamaan Langmuir dan Freundlich. Dengan nenggunakan kedua formula ini, maksimum ;orpsi $P$ dapat diduga begitu juga dengan $P$ yang diperlukan oleh tanaman untuk sertumbuhannya yang optimal yaitu 0.2 ngkg $^{-1}$. Data $P$ yang terjerap dan $P$ yang erekstrak selanjutnya dihubungkan dengan zomponen tanah 
Marapi serta pada toposequen G. Pasaman lainnya terutama senyawa aktif $\mathrm{Al}$ dan $\mathrm{Fe}$.

\section{HASIL DAN PEMBAHASAN}

\section{A. Sifat Asli Tanah}

Untuk mengetahui sifat tanah yang diperkirakan berpengaruh terhadap sorpsi $\mathbf{P}$ maka dilakukan analisis beberapa sifat fisika, kimia dan mineral tanah dengan hasil seperti tercantum dalam Tabel 1 dan 2. Reaksi (pH) tanah vulkanis yang diteliti agak masam dan merupakan sifat atau cini dari tanah yang relatif muda dan berkembang dari bahan induk vulkanis. Delta pH (pH $\left.\mathrm{KCl}-\mathbf{p H} \mathbf{H}_{2} \mathrm{O}\right)$ walaupun bemilai negatif tetapi angkanya mendekati nol. Hal ini berarti tanah mempunyai kecendrungan bermuatan permukaan hampir tidak ada atau nol. Kapasitas tukar kation dan kejenuhan basa termasuk criteria sedang. Seluruh tanah yang diteliti memenuhi persyaratan penciri sifat tanah andik sehingga dapat diklasifikasikan ke dalam ordo Andisol pada system klasifikasi Taksonomi Tanah USDA.

Sifat fisika tanah vulkanis G. Marapi dan G. Pasaman ini dicirikan dengan rendahnya nilai berat volume (BV / bulk density) tanah. Mineral liat non-kristalin seperti alofan memegang peranan utama dalam menentukan rendahnya nilai BV tanah vulkanis Sumatera Barat ini. Nilai BV berbanding terbalik dengan kadar Si yang diekstrak dengan oksalat. Semakin tinggi kadar Si yang berarti semakin banyak alofan di dalam maka semakin rendahlah nilai BV tanah vulkanis. Tan (1998) menyatakan bahwa alofan berbentuk seperti bola-bola kosong yang mempunyai banyak sekali pori-pori intra dan inter partikel. Nilai BV juga ditentukan oleh partikel density dari alofan. Fiantis (2000) melaporkan bahwa partikel density dari tanah vulkanis yang ditelitinya berkisar antara 2.13 sampai $2.48 \mathrm{Mg}$ $\mathbf{m}^{-3}$. Nilai partikel density ini lebih rendah daripada partikel density standar yang biasa digunakan yaitu partikel densiti dari kuarsa.

Kadar C organic dari Andisols ini berkisar antara 3-10\% atau setara dengan bahan organic $6-20 \%$. Nilai ini tergolong cukup tinggi bila dibandingkan dengan kadar $\mathrm{C}$ organik tanah mineral lainnya seperti Ultisol ataupun Oxisol. Tingginya kadar $\mathrm{C}$ organik ıdalah akibat akumulasi bahan organik pada corizon permukaan. Disyaratkan oleh Soil Survey Staff (1999) bahwa akumulasi bahan srganik dari tanah vulkanis dapat mencapai 25 persent. Terjadinya akumulasi bahan srganik yang tinggi pada tanah vulkanis likarenakan bahan organik terikat kuat oleh lofan sehingga proses dekomposisi rerlangsung lebih lambat (Shoji et al., 1993). Ditambahkan oleh Tan (1998) bahwa Al dan Fe terbuka yang berada di permukaan alofan rereaksi dan membentuk khelat dengan asam numat sehingga asam humat ini terlindung lari serangan enzim atau mikroba tanah yang nencoba untuk menguraikannya yang serakibat terjadinya penumpukan bahan srganik pada horizon permukaan dan warna anah menjadi gelap atau kehitaman.

Jumlah kation-kation yang dapat litukarkan terutama $\mathrm{Ca}$ dan $\mathrm{Mg}$ tergolong ;edang sampai tinggi pada tanah vulkanis G. Marapi. Hal ini tidaklah mengherankan zarena sering terjadi penambahan kation dari etusan debu vulkanik G. Marapi. Debu vulkanik dari Indonesia menurut Tan (1998) Imumnya bersifat basalto-andesitik yang sanyak mengandung Ca dan Mg. Sedangkan ilai KTK yang berkisar antara $24-52$ cmol $_{c}$ $\mathrm{zg}^{-1}$ termasuk criteria sedang hingga tinggi. Tetapi Van Ranst (1995) dan Fiantis (2000) nengemukakan bahwa nilai KTK ini idaklah menggambarkan keadaan yang sebenamya di lapangan. Hal ini disebabkan senentuan KTK tanah dilakukan pada pH 7 ;edangkan $\mathrm{pH}$ tanah vulkanis yang diteliti rerada antara 4.7 - 5.9. Bila pH tanah linaikkan satu atau dua unit lebih tinggi, Ikan terjadi penambahan muatan negatif anah artifisial sehingga KTK yang dianalisis lengan menggunakan Ammonium Acetat jada pH 7 menghasilkan nilai KTK yang idak riil dari keadaan yang sebenamya.

\section{P sorption Isotherm}

Andisols dari G. Pasaman mempunyai semampuan menjerap $P$ yang berbeda cukup yyata bila dibandingkan dengan tanah $G$. Marapi. Pada tanah G. Pasaman, P baru lapat dideteksi pada lanutan tanahnya bila litambahkan sebesar $\quad 120 \mu \mathrm{g} \quad \mathrm{P} \mathrm{ml}^{-1}$ ;edangkan pada tanah G. Marapi sudah 
terdeteksi pada konsentrasi $60 \mu \mathrm{g} \quad \mathbf{P} \quad \mathrm{ml}^{-1}$.

Tablel 3 and Tabel 4 menyajikan hasil analisis $P$ sorption isotherm dengan menggunakan persamaan Langmuir dan Freundlich.

Berdasarkan persamaan isothem Langmuir maka diperoleh nilai sorpsi (sorpsi) P maksimum dari tanah vulkanis G. Marapi lebih rendah bila dibandingkan dengan tanah vulkanis G. Pasaman. Kapasitas sorpsi P tanah vulkanis Sumatera Barat ini temyata hampir sama dengan kapasitas sorpsi $P$ pada tanah vulkanis lainnya seperti dari Jepang dan Selandia Banu (Kawai, 1979; Imai et al., 1981). Faktor yang sangat mempengaruhi kapasitas suatu tanah untuk menjerap $P$ adalah susunan mineral utama yang terdapat pada tanah itu (Shoji et al., 1993; Tan, 1998).

Tanah pada horizon permukaan (surface) temyata mempunyai kemampuan menjerap $\mathbf{P}$ yang lebih rendah bila dibandingkan pada tanah lapisan bawah (subsurface). Hal ini juga berkaitan dengan keberadaan mineral alofan yang lebih rendah bila dibandingkan dengan alofan yang terdapat pada horizon bawah permukaan serta kadar bahan organik tanah yang lebih banyak pada horizon permukaan. Sibanda and Young (1986) melaporkan bahwa asan humat dan fulvat yang dikandung oleh bahan organik tanah dapat menurunkan sorpsi $P$ akibat terjadinya kompetisi untuk memperebutkan tempat adsorpsi pada permukaan alofan.

Jumlah $\mathbf{P}$ yang terjerap meningkat seiring dengan bertambahnya konsentrasi $P$ dalam larutan tanah seperti terlihat pada Gambar 13 berikut ini. Reaktivitas sorpsi meningkat dengan cepat yang diperlihatkan dari bentuk kurva yang hampir sejajar dengan sumbu ordinat (Y) hingga jumlah $P$ terjerap mencapai maksimum yaitu pada saat kurva mendatar dan sejajar dengan sumbu $X$. Kurva adsorpsi pada horison permukaan berbentuk huruf $L$ sedangkan pada horizon bawah-permukaan kurva berbentuk huruf $\mathrm{H}$.

Menurut Tan (1992) kedua kurva baik berbentuk $L$ ataupun $H$ dicirikan oleh afinitas yang tinggi dari bahan padat tanah terhadap larutan tanah tetapi kurva tipe $\mathrm{H}$ mempunyai zapasitas sorpsi yang lebih besar bila libandingkan dengan kurva berbentuk $L$. Pada kurva $H$ hampir seluruh $P$ yang berada Jada larutan tanah dijerap oleh partikel anah sehingga tidak ada lagi yang tersisa lidalam larutan tanahnya. Seluruh kurva nempunyai korelasi logaritma yang tinggi $\mathbf{R}^{2}>$ 0.91) yang berarti selunuh data adsorpsi sesuai bila dianalisis dengan nenggunakan persamaan / model adsorpsi Langmuir. Sebaliknya bila diuji dengan sorelasi linear, nilainya lebih rendah bila libandingkan dengan logaritma. Hal ini nengisyaratkan bahwa model adsorpsi untuk anah vulkanis sebaiknya berbentuk ogaritma dan bukan berbentuk linear.

Dari kurva sorpsi $\mathbf{P}$ dapat dibuat dua zaris yang saling memotong yang dan liinterpretasikan bahwa tempat (site)adsorpsi jada permukaan mineral lebih dari satu dan oroses adsorpsi berlangsung tidak homogen. Ryden at al. (1977) melaporkan bahwa erdapat tiga tipe dan tempat adsorpsi $P$ yaitu Jada daerah (region) I, II dan III yang nasing-masing mempunyai reaktivitas yang rerbeda berakibat terdapatnya energi sengikatan yang berlainan dan jumlah $\mathbf{P}$ naximum yang berbeda pula. Jadi, peneliti ni menyarankan untuk memodifikasi sersamaan asal Langmuir yang sederhana nenjadi persamaan Langmuir duarermukaan (two-surface equations).

Persamaan Langmuir yang asli lebih epat digunakan bila konsentrasi $P$ pada arutan tanah rendah dan pada kisaran yang erbatas. Sementara itu menurust Sanyal dan Datta (1991) dengan menggunakan sersamaan dua-muka Langmuir, adsorpsi yang terjadi lebih realistis jika dibandingkan lengan persamaan satu-muka Langmuir. Sebenarnya penggunaan dan validitas sersamaan satu muka atau dua-muka Langmuir masih diperdebatkan oleh para seneliti lainnya seperti oleh Parfitt (1978), Sposito (1982) dan Lin et al. (1983), tetapi opik ini sudah diluar dari konteks sembahasan makalah ilmiah ini. 
Tabel 1. Beberapa sifat kimia tanah dari horizon A Andisols G. Marapi dan G. Pasaman

\begin{tabular}{|c|c|c|c|c|c|c|c|c|c|}
\hline \multirow{2}{*}{ Soils } & \multirow{2}{*}{$\begin{array}{c}\text { pH } \\
\text { (H }\end{array}$} & \multirow{2}{*}{$\Delta$ pH } & Ca & Mg & K & Na & KTK (pH $)$ & BS \\
\cline { 3 - 7 } & & & \multicolumn{5}{|c|}{${\text { cmol } \text { kg }^{-1} \text { soil }}^{*}$} \\
\hline I M & 5.15 & -0.47 & 3.22 & 0.58 & 0.25 & 0.15 & 24.09 & 17 \\
II M & 5.31 & -1.02 & 11.80 & 1.89 & 0.26 & 0.28 & 24.59 & 35 \\
III M & 5.71 & -0.53 & 19.71 & 3.72 & 2.05 & 0.20 & 40.57 & 63 \\
IV M & 5.98 & -0.97 & 8.98 & 1.16 & 0.50 & 0.31 & 28.23 & 39 \\
VM & 5.97 & -1.11 & 8.42 & 3.16 & 1.60 & 0.20 & 28.59 & 46 \\
VI P & 4.81 & -0.21 & 2.45 & 0.68 & 0.99 & 0.23 & 37.25 & 11 \\
VII P & 4.68 & 0.03 & 0.92 & 0.32 & 0.25 & 0.15 & 36.42 & 5 \\
VIII P & 5.57 & -0.66 & 8.22 & 1.61 & 0.24 & 0.14 & 52.74 & 19 \\
IX P & 5.61 & -0.68 & 3.35 & 0.49 & 0.10 & 0.16 & 31.72 & 13 \\
\hline
\end{tabular}

Tabel 2. Beberapa sifat fisika dan mineral tanah dari horizon A Andisols G. Marapi dan G. Pasaman

\begin{tabular}{|c|c|c|c|c|c|c|}
\hline \multirow{2}{*}{ Soils } & Clay & C & \multirow{2}{*}{$\begin{array}{c}\text { P-ret } \\
\%\end{array}$} & \multirow{2}{*}{$\begin{array}{c}\mathrm{Al}_{\mathrm{O}}+1 / 2 \mathrm{Fe}_{\mathrm{O}} \\
\%\end{array}$} & \multirow{2}{*}{$\begin{array}{c}\text { BD } \\
\mathrm{Mg} \mathrm{m}^{-3}\end{array}$} & \multirow{2}{*}{$\begin{array}{c}\text { Allophane } \\
(\%)\end{array}$} \\
\hline & \multicolumn{2}{|c|}{$\%$} & & & & \\
\hline I M & 23 & 7.24 & 93 & 3.95 & 0.89 & 10 \\
\hline II M & 32 & 7.6 & 85 & 2.44 & 0.73 & 18 \\
\hline III M & 29 & 6.87 & 86 & 2.91 & 0.89 & 7 \\
\hline IV M & 18 & 5.28 & 86 & 2.94 & 0.88 & 6 \\
\hline VM & 57 & 3.00 & 86 & 2.05 & 0.63 & 0 \\
\hline VIP & 45 & 8.05 & 98 & 6.82 & 0.74 & 22 \\
\hline VII P & 57 & 7.02 & 95 & 6.58 & 0.70 & 33 \\
\hline VIII P & 43 & 10.14 & 97 & 6.30 & 0.77 & 17 \\
\hline IX P & 58 & 7.38 & 97 & 4.31 & 0.75 & 12 \\
\hline
\end{tabular}

Tabel 3. Parameter Jerapan P isotherm dari tanah G. Marapi

\begin{tabular}{|c|c|c|c|c|c|}
\hline \multirow[b]{2}{*}{ Profiles Horizons } & \multicolumn{2}{|c|}{ Langmuir } & \multirow{2}{*}{$\begin{array}{l}P \text { added to } \\
0.2 \text { mgkg }^{-1}\end{array}$} & \multicolumn{2}{|c|}{ Freundlich } \\
\hline & $\underset{\text { mg kg }^{-1}}{\text { PSM }}$ & $\begin{array}{c}\mathbf{K} \\
\mathbf{L} \mathbf{~ m o l}^{-1}\end{array}$ & & $\begin{array}{c}\text { PSM } \\
\text { mg kg }^{-1}\end{array}$ & $\begin{array}{c}\text { Slope } \\
\text { L mol }^{-1}\end{array}$ \\
\hline I M $\quad$ Surface & 1012 & 8714 & 1676 & 960 & 0.43 \\
\hline Subsurface & 1016 & 14571 & 2696 & 1037 & 0.34 \\
\hline II M Surrace & 959 & 7182 & 1346 & 798 & 0.31 \\
\hline Subsurface & 980 & 11138 & 1993 & 847 & 0.31 \\
\hline IIT Sufoce & 856 & 810 & 1337 & 301 & 0.50 \\
\hline II M Sunace & 933 & 7378 & 1341 & 609 & 0.31 \\
\hline Subsurface & 839 & 1932 & 320 & 439 & 0.36 \\
\hline IV M Surface & 839 & 3154 & 519 & 509 & 0.30 \\
\hline Surfora & 593 & 14108 & 1534 & 710 & 0.57 \\
\hline Subsurface & 986 & 19250 & 2178 & 1137 & 0.28 \\
\hline
\end{tabular}


Tabel 4. Parameter Jerapan $P$ isothem dari tanah G. Pasaman

\begin{tabular}{|c|c|c|c|c|c|c|}
\hline \multirow{2}{*}{\multicolumn{2}{|c|}{ Profiles Horizons }} & \multicolumn{2}{|c|}{ Langmuir } & \multirow{2}{*}{$\begin{array}{l}P \text { added to } \\
0.2 \mathrm{mg} \mathrm{kg}^{-1}\end{array}$} & \multicolumn{2}{|c|}{ Freundlich } \\
\hline & & $\begin{array}{c}\text { PSM } \\
\text { mg kg-1 }^{-1}\end{array}$ & $\underset{\mathbf{L ~ m o l}^{-1}}{\mathrm{~K}}$ & & $\begin{array}{c}\text { PSM } \\
\mathrm{mg} \mathrm{kg}^{-1}\end{array}$ & $\begin{array}{l}\text { Slope } \\
\text { L mol }^{-1}\end{array}$ \\
\hline \multirow[t]{2}{*}{ VIP } & Surface & 1973 & 17444 & 6186 & 1863 & 0.19 \\
\hline & Subsurface & 1998 & 15500 & 5131 & 1869 & 0.20 \\
\hline \multirow[t]{2}{*}{ VII P } & Surface & 1986 & 19500 & 6882 & 1921 & 0.19 \\
\hline & Subsurface & 2011 & 15400 & 5635 & 1928 & 0.21 \\
\hline \multirow{2}{*}{ VIII P } & Surface & 1998 & 17222 & 6194 & 2050 & 0.25 \\
\hline & Subsurface & 2051 & 21571 & 7768 & 2497 & 0.31 \\
\hline \multirow[t]{2}{*}{$\mathbf{I X} \mathbf{P}$} & Surface & 2011 & 6160 & 2383 & 1625 & 0.27 \\
\hline & Subsurface & 1973 & 17444 & 6186 & 1932 & 0.22 \\
\hline
\end{tabular}

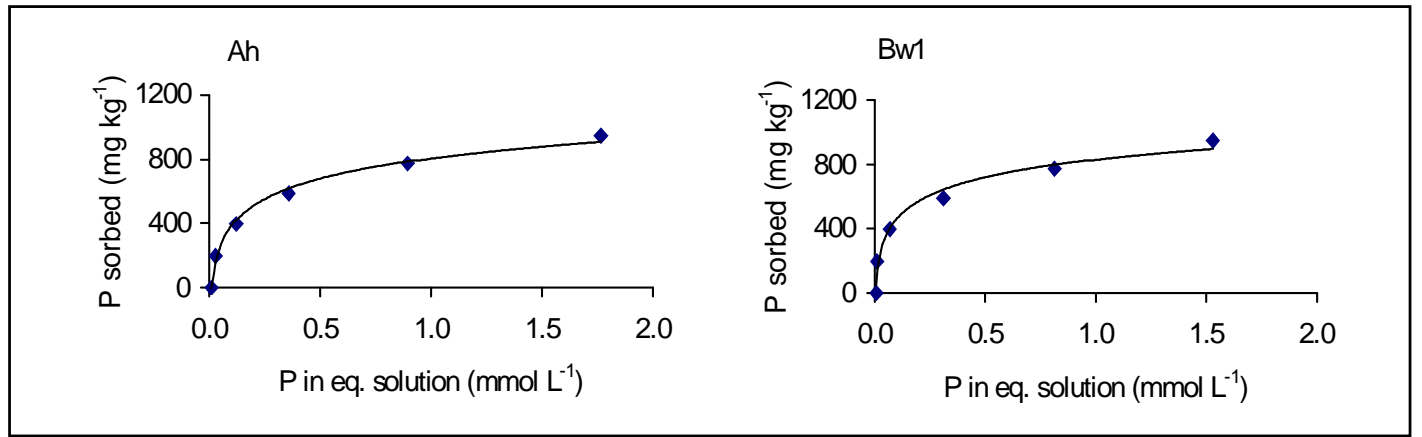

Gambar 1. Kurva isotherm adsorpsi untuk tanah vulkanis G. Marapi ( II M)
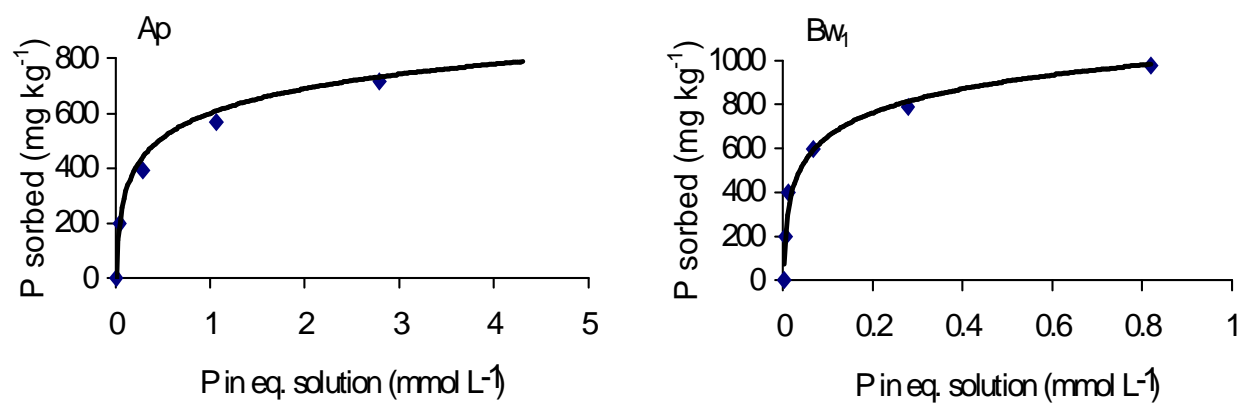

Gambar 2. Kurva isotherm adsorpsi untuk tanah vulkanis G. Marapi (V M)
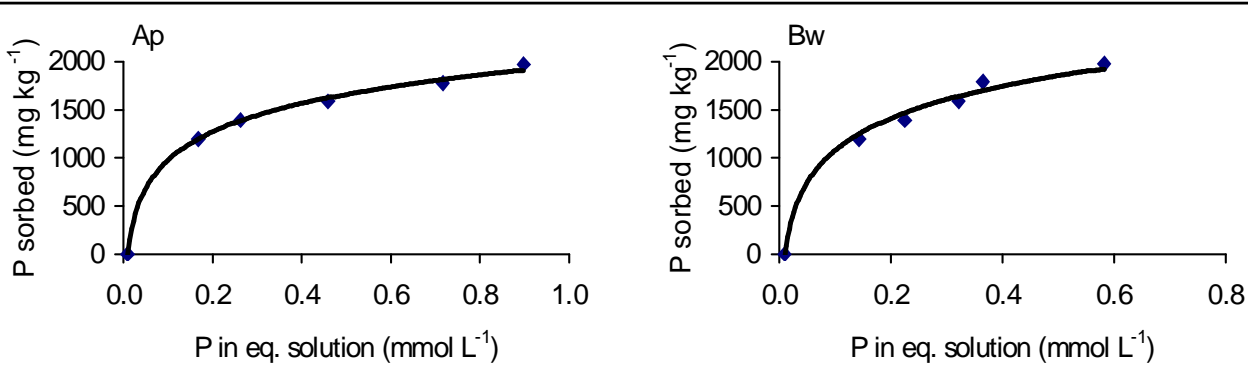

Gambar 3. Kurva isotherm adsorpsi untuk tanah vulkanis G. Pasaman ( VIII P) 
Setelah dilakukan analisis regresi antara $\mathbf{P}$ terjerap maksimum dengan berbagai komponen penyusun tanah, temyata alofan menunjukan korelasi yang tinggi dengan jumlah $P$ yang terjerap (Gambar 4). Terjadi peningkatan sorpsi $P$ dengan bertambahnnya jumlah alofan dalam tanah. Tetapi sebaliknya tidak terdapat hubungan yang signifikan antara $P$ yang terjerap dengan bahan organik tanah. Hasil yang sama juga dilaporkan oleh Borggaard et al. (1990); bahwa temyata bahan organik tidak mempengaruhi besarnya sorpsi P. Ini dilakukan dengan cara mengoksidasi bahan organik dengan $\mathrm{H}_{2} \mathrm{O}_{2}$ dan setelah itu dilakukan analisis sorpsi $\mathbf{P}$ dengan hasil sorpsi $\mathbf{P}$ tidak berubah.

Kapasitas sorpsi $\mathbf{P}$ tanah yang diteliti dapat dikelompokan menjadi 3 kelompok yaitu (1) sorpsi $P$ maksimum $>2000 \mathrm{mg} P \mathrm{~kg}^{-1}$, (2) sorpsi $P$ maksimum antara 800 to 1000 , dan (3) sorpsi $P$ maksimum dibawah $700 \mathrm{mg} P \mathrm{~kg}^{-}$ 1. Tanah vulkanis G. Pasaman temyata mempunyai sorpsi $\mathbf{P}$ yang paling besar diikuti oleh tanah vulkanis G. Marapi yang terletak pada lereng sebelah selatan dan yang paling rendah sorpsi $\mathbf{P}$ terjadi pada tanah vulkanis $\mathbf{G}$. Marapi sebelah utara. Level kritis dari alofan untuk dapat menjerap $P$ adalah pada konsentrasi $11 \%$ untuk tanah G. Pasaman yang

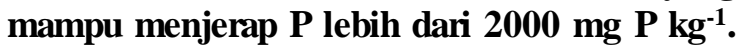
Sedangkan pada tanah G. Marapi dengan kadar alofan 5\% temyata $P$ yang terjerap sebesar 900 $\mathrm{mg} \mathrm{P} \mathrm{kg}{ }^{-1}$.

Nilai afinitas sorpsi (K) $P$ atau energi pengikatan $P$ yang didapatkan temyata bervariasi antara tanah G. Marapi dan G. Pasaman. Nilai $K$ cendrung meningkat sejalan dengan kedalaman tanah yang berarti energi untuk mengikat $\mathbf{P}$ lebih besar pada horizon bawah-permukaan daripada horizon permukaan tanahnya. Juga dapat disebutkan pada tanah G. Pasaman, P terikat lebih kuat bila dibandingkan dengan $P$ yang terikat pada tanah G. Marapi., mengakibatkan P lebih sulit tersedia bagi tanaman yang tumbuh di Tanah vulkanis G. Pasaman.
Jumlah kebutuhan P standar (KPS) yaitu pada konsentrasi $P$ larutan tanah setelah reaksi setimbang $0.2 \mathrm{mg} \mathrm{P} \mathrm{kg}^{-1}$ baru tercapai pada sorpsi $P$ sekitar 1000 - 2000 mg $P$ kg $^{-1}$ untuk Tanah G. Marapi dan pada konsentrasi 2000 - $6000 \mathrm{mg} P \mathrm{~kg}^{-1}$. Ini berarti diperlukan tingkat pemupukan $P$ yang tinggi sampai sangat tinggi agar tercapai suplai $P$ yang cukup untuk tanaman. Hal yang sama juga dilaporkan terjadi pada tanah vulkanis di Jepang (547 - 2861 mg P kg1), Hawaii (763 - $\left.1096 \mathrm{mg} \mathrm{P} \mathrm{kg}^{-1}\right)$ dan di pulau Jawa lebih dari $2630 \mathrm{mg} P \mathrm{~kg}^{-1}$ (Kawai, 1980; Syarif, 1990).

Secara umum persamaan Langmuir nemberikan data yang lebih tepat libandingan dengan persamaan Freundlich. Koefisien korelasi yang dihasilkan lebih inggi bila dibandingkan dengan koefisen zorelasi dari data yang dianalisis dengan xersamaan Langmuir. Model sorpsi Freundlich juga menggunakan asumsi ogaritma dan meningkat seiring dengan raiknya konsentrasi $P$ dalam larutan tanah.

Tanah G. Pasaman mempunyai koefisien zorelasi antara $P$ yang terjerap dengan $P$ pada arutan setimbang yang lebih tinggi bila libandingakn dengan hasil dari Tanah G. Marapi tetapi perbedaan ini berbeda tidak yyata. Kurva sorpsi P pada model Freundlich valid hanya pada konsentrasi $P$ dari sedang lingga tinggi. Hasil yang sama juga lilaporkan Singh and Gilkes (1991) dan Sanyal and Datta (1991).

Nilai K dari persamaan Freundlich dapat ligunakan untuk memprediski sorpsi $\mathbf{P}$ naksimum temyata lebih rendah dari pada ilai yang didapat dengan menggunkan persamaan Langmuir. Tetapi jika kedua nilai ni dikorelasikan, temyata keduanya nempunyai hasil yang berbeda tidak nyata. Salah satu kelemahan persamaan Freundlich Idalah tidak dapat memprediski jumlah $\mathbf{P}$ yang harus ditambahkan ke dalam tanah intuk pertumbuhan optimum tanaman. 


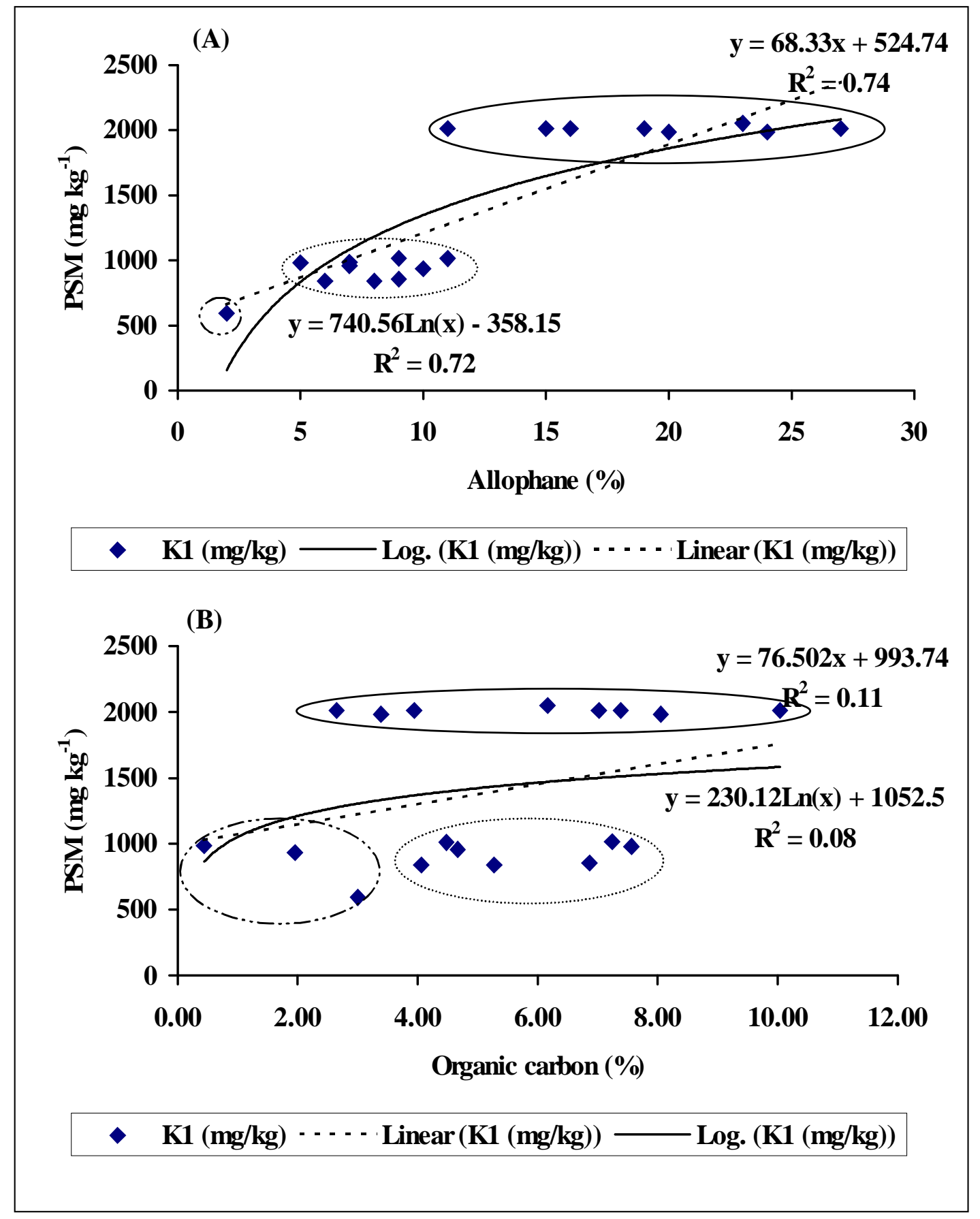

Gambar 6: Hubungan antara $P$ terjerap maksimum dengan (a) alofan) dan (b) C organik 
Jumlah kebutuhan P standar (KPS) yaitu pada konsentrasi $P$ larutan tanah setelah reaksi setimbang $0.2 \mathrm{mg} \mathrm{P} \mathrm{kg}^{-1}$ baru tercapai pada sorpsi P sekitar 1000 - 2000 mg $P$ kg $^{-1}$ untuk Tanah G. Marapi dan pada konsentrasi 2000 $6000 \mathrm{mg} \mathrm{P} \mathrm{kg}^{-1}$. Ini berarti diperlukan tingkat pemupukan $P$ yang tinggi sampai sangat tinggi agar tercapai suplai $\mathbf{P}$ yang cukup untuk tanaman. Hal yang sama juga dilaporkan terjadi pada tanah vulkanis di Jepang (547

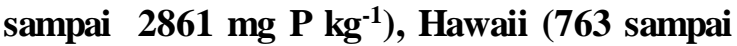
$1096 \mathrm{mg} \mathrm{P} \mathrm{kg}^{-1}$ ) dan di pulau Jawa lebih dari $2630 \mathrm{mg} \mathrm{P} \mathrm{kg}^{-1}$ (Kawai, 1980; Syarif, 1990).

Secara umum persamaan Freundlich memberikan data yang lebih tepat dibandingan dengan persamaan Freundlich. Koefisien korelasi yang dihasilkan lebih tinggi bila dibandingkan dengan koefisen korelasi dari data yang dianalisis dengan persamaan Langmuir. Model sorpsi Freundlich juga menggunakan asumsi logaritma dan meningkat seiring dengan naiknya konsentrasi $P$ dalam lanutan tanah

Tanah G. Pasaman mempunyai koefisien korelasi antara $P$ yang terjerap dengan $P$ pada larutan setimbang yang lebih tinggi bila dibandingakn dengan hasil dari tanah $G$. Marapi tetapi perbedaan ini berbeda tidak nyata. Jika diperhatikan kurva sorpsi $P$ pada model Freundlich (Gambar 7 dan Gambar 8) terlihat model valid hanya pada konsentrasi $\mathbf{P}$ dari sedang hingga tinggi. Hasil yang sama juga dilaporkan Singh and Gilkes (1991) dan Sanyal and Datta (1991).

Nilai K dari persamaan Freundlich dapat digunakan untuk memprediski sorpsi $\mathbf{P}$ maksimum temyata lebih rendah dari pada nilai yang didapat dengan menggunkan persamaan Langmuir. Tetapi jika kedua nilai ini dikorelasikan, temyata keduanya mempunyai hasil yang berbeda tidak nyata. Salah satu kelemahan persamaan Freundlich adalah kita tidak dapat memprediski jumlah $P$ yang harus ditambahkan ke dalam tanah untuk pertumbuhan optimum tanaman Pertanian. .

\section{KESIMPULAN DAN SARAN}

Tanah vulkanis G. Pasaman mempunyai kapasitas sorpsi yang lebih tinggi bila dibandingkan dengan Tanah G. Marapi mengakibatkan kebutuhan $P$ untuk pertumbuhan tanaman yang optimum harus lebih besar. Sifat Tanah yang paling dominan terhadap pola dan jumlah sorpsi $P$ adalah tipe mineral liat tanah yang dominan dijumpai pada Tanah vulkanis yaitu mineral liat non-kristalin (alofan dan ferihidrit) yang merupakan komponen koloid $\mathrm{Al}$ dan $\mathrm{Fe}$ aktif.

\section{Ucapan Terima Kasih}

Penulis menyampaikan ucapan terima kasih kepada Lembaga Penelitian Universitas Andalas melalui bantuan dana dalam Proyek Penelitian Doktor Muda SPP/DPP tahun 2001 dengan kontrak No. 11/LP-UA/SPP-DPP/D/V/2001.

\section{DAFTAR PUSTAKA}

Ahmad, F., I. N. Dt. R. Imbang, E. Farda, D. Fiantis. 1994. Peranan Mineral Liat Non Kristalin Dalam Pembentukan Tanah Berbahan Induk Abu Vulkanis Pada Toposequen G. Merapi dan G. Talamau di Sumatera Barat. Lembaga Penelitian Universitas Andalas. Padang. 56 p.

Allen, B. L. and B.F. Hajek. 1989. Mineral occurrence in Soil Environments. In : J.B. Dixon and S. B. Weed. Minerals in Soil Environments. SSSA. Madison. pp. 199-277.

Blakemore, L.C., P.L. Scarle, and B. K. Daly. 1987. Soil Bureau Laboratory Methods for chemical analysis of soil. New Zealand Soil Bureau. Soil Rep. 10A. DSIRO. New Zealand.

Borggard, O. K., S. S. Jorgensen, J. P. Moberg and B. Raben-Lange. 1990. Influence of organic matter on phosphate adsorption by aluminium and iron oxides in sandy soils. J. of Soil Sci. 41:443449. 
Brawell, J. M., A.C. Campbell, and B. D. Mitchell. 1970. An Assignment of some thermal \& chemical technique used in the study of the poorly ordered aluminosilicates in soil clays. Clay Mineralogy 8 : 325-335.

Egawa, T. 1977. Properties of Soil Derived from Volcanic Ash Soils. In K. H. Tan (ed.). 1984. Andosols. Van Nostrand Reinhold Comp. New York. pp. 249302.

FAO-ISRIC-ISSS. 1998. World Reference Base for Soil Resources. World Soil Resources Reports No. 84. FAO of UN. Rome.

Farmer, V. C., W. J. McHardy, F. Palmieri, A. Violante, and P. Violante. 1991. Syntethic allophanes formed in calcareous environments; Nature, conditions of formation and transformations. SSSA Journal Vol. 55: 1162-1166.

Fiantis, D. 1995. Properties of Volcanic Ash Soils from the Marapi and Talamau Volcanoes in West Sumatera (Indonesia). M. Sc. thesis. Universiteit Gent. 131 p.

Fiantis, D. 2000. Colloid-Surface Characteristics and Amelioration Problems of some volcanic soils in West Sumatra, Indonesia. Ph. D. Thesis. Universiti Putra Malaysia, Serdang, Selangor, Malaysia. 315 p.

Imai, H., K. W. T. Goulding and $O$. Talibudeen. 1981. Phosphate adsorption in allophanic soils. J. of Soil Sci. 32:555-570.

Jackson, 1965. Free Oxides, ydroxides and amorphous aluminosilicates. In Black (ed.) Methods of soil analysis Part I. Physical and Mineralogical Properties. Amer. Soc. of Agronomy. Madison.

Juo, A. S. R. and R. L. Fox. 1977. Phosphate sorption capacity of some benchmark soils in West Africa. Soil Sci. 124:370376.

Kawai, K. 1980. The relationship of phosphorus adsorption to amorphous aluminum for characterizing Andosols. Soil Sci. 129: 186-190.

Lin, C., W. J. Busscher, and L. A. Douglas. 1983. Multifactor kinetics of phosphate reactions with minerals in acidic soils. I. Modeling and simulation. Soil Sci. Soc. Am. J. 47:1097-1103.

Parfitt, R. L. 1978. Anion adsorption by soils and soil materials. Adv. Agronomy, 30:1-50.

Parfitt, R. L., and T. Henmi. 1982. Comparison of an oxalate-extraction method and an infrared spectroscopic method for determining allophane in soil clays. Soil Sci. Plant Nutr., 28:183-190.

Parfitt, R. L., and A. D. Wilson. 1985. Estimation of Allophane anf Halloysite in three sequences of volcanic ash soils New Zealand. In E. Femandez Caldas and D.H. Yaolan (editors). Volcanic Soils. Catena Suppl. 7:1-8.

Sanyal S. K., and S. K. De Datta. 1991. Chemistry of phosphorus transformation in soils. In B. A. Stewart (ed.), Advances in Soil Sci. Springer-Verlag. New York.

Singh, B. and R. J. Gilkes. 1991. Phosphorus sorption in relation to soil properties for the major soil types of South-westem Australia. Aust. J. Soil Res. 29:603-618.

Sibanda, H. M. and S. D. Young. 1986. Competitive adsorption of human acids and phosphate on goethite, gibbsite and two tropical soils. J. Soil Sci. 37:197-204.

Shoji, S., M. Nanzyo, and R. Dahlgren. 1993. Volcanic Ash Soils. Elsevier. Amsterdam. 288 p.

Soil Survey Staff. 1999. Soil Taxonomy. A Basic system of Soil Classification for Making and Interpreting Soil Surveys. $2^{\text {nh }}$ ed. USDA, NRCS. Washington. 846 p. 
Syarif, S. 1990. Some characteristics of Andisols from Westem Indonesia. Ph.D. thesis, Univ. Westem Australia, Soil Sci. and Plant Nutr., School of Agric. 247 pp.

Sposito, G. 1984. The surface chemistry of soils. Clarendom Press. Oxford. 234 p.

Tan, K.H. 1984. Andosols. Van Nostrand Reinhold Company. New York. 418 p.

Tan, K.H. 1992. Principle of Soil Chemistry (2nd ed.). Marcell Dekker. New York. 352 p.

Tan, K. H. 1998. Andosols. Program Studi Ilmu Tanah Program Pascasarjana Universitas Sumatera Utara. Medan. 75 p.
Van Bemmelen, R. W. 1970. The Geology of Indonesia, vol. I A. Martinus Nijhoff. The Hague.

Van Ranst, E. 1995. Clay Mineralogy. Lecture Notes. ITC for Post-Graduate Soil Scientists University of Gent. 287 p.

Wada, K. 1985. The distinctive properties of Andosols. Stewart B. A. (ed.) In advances in Soil Science vol 2 . Springer Verlang. New York. Pp. 173-229.

Wada, K. 1989. Allophane and Imogolite. In : J.B. Dixon and S. B. Weed. Minerals in Soil Environments. SSSA. Madison. pp. 1051-1087. 